\title{
Coral-algal competition: macroalgae with different properties have different effects on corals
}

\author{
Jamaluddin Jompa ${ }^{1,2,3}$, Laurence J. McCook ${ }^{2,4, *}$ \\ ${ }^{1}$ Department of Marine Biology, James Cook University, Townsville, Queensland 4811, Australia \\ ${ }^{2}$ Australian Institute of Marine Science and CRC Reef Research, PMB 3, Townsville, MC, Queensland 4810, Australia \\ ${ }^{3}$ Present address: Faculty of Marine Science and Fisheries, Hasanuddin University, Makassar 90245, Indonesia \\ ${ }^{4}$ Present address: Great Barrier Reef Marine Park Authority, PO Box 1379, Townsville, Queensland 4810, Australia
}

\begin{abstract}
Competition between hard corals and macroalgae is a key ecological process on coral reefs, especially during reef degradation, which often involves a 'phase-shift' from coral- to algadominated reefs. However, there are relatively few published studies exploring the variability in this interaction. This paper expands the range of documented coral-algal interactions by comparing the mechanisms and outcomes of interactions involving 3 different algal species, as well as general, mixed algal turfs. Mixed filamentous turfs had relatively minor effects on corals. However, the turfing filamentous red alga Corallophila huysmansii provided a dramatic exception to this pattern, being able to settle on, overgrow and kill live coral tissue, perhaps due to allelochemical production by the alga, although this was not directly demonstrated. The larger filamentous alga Chlorodesmis fastigiata ('Turtle Weed'), which is conspicuous and abundant on Indo-Pacific reefs, caused polyp retraction but had little other noticeable effect on coral tissue. A corticated red alga Hypnea pannosa, frequently observed living within colonies of the branching coral Porites cylindrica, did not have a major impact on underlying coral tissue, even over a period of $1 \mathrm{yr}$, apparently because its relatively translucent and porous thallus structure does not strongly inhibit coral tissue functions. Together, the results demonstrate the considerable potential variability in both the process and outcome of coral-algal competition. This variability can be effectively interpreted in terms of the limited number of mechanisms by which algae can affect corals, with these mechanisms depending largely on the properties (physical, biological, chemical) of the algae. Given the central importance of coral-algal competition to the process of coral reef phase-shifts, understanding the variability and complexity in such competition will have important implications for the prediction and consequences of such phase-shifts.
\end{abstract}

KEY WORDS: Coral-algal competition - Algal functional groups - Filamentous algal turfs - Corticated algae $\cdot$ Life-history traits $\cdot$ Porites spp. $\cdot$ Corallophila huysmansii $\cdot$ Chlorodesmis spp.

Resale or republication not permitted without written consent of the publisher

\section{INTRODUCTION}

Competition is a key process determining the structure and composition of benthic communities on coral reefs (Lang \& Chornesky 1990, Karlson 1999). In particular, competition between hard corals and benthic algae is fundamental to the overall status of coral reefs, especially during reef degradation. Coral reef degradation commonly involves a so-called phase-shift from reefs dominated by corals to reefs dominated by benthic algae (Done 1992, Hughes 1994, McCook 1999).
There has been considerable recent controversy over the relative importance of bottom-up processes, such as eutrophication (e.g. Lapointe 1997, 1999), and topdown control by herbivores (Hughes 1994, Hughes et al. 1999, Aronson \& Precht 2000) in contributing to these changes, particularly in the context of declines in Caribbean reefs. According to the bottom-up model, excess nutrient supply results in an increased growth of benthic algae (e.g. Hanisak 1979, Lapointe 1997, Schaffelke \& Klumpp 1998, Schaffelke 1999), leading to overgrowth of corals and consequent reef degrada- 
tion (Smith et al. 1981, Pastorok \& Bilyard 1985, Bell 1992, Naim 1993, Lapointe 1999). The top-down model argues that algal biomass is predominantly controlled by herbivore consumption (e.g. Hay 1981, 1984, Lewis 1985, 1986, Hughes 1994, McCook 1996, 1997, Russ \& McCook 1999) and that phase shifts are often the result of declines in herbivores, with consequent increases in algal abundance and competitiveness.

However, it is important to recognise that competition between corals and algae is a critical step in both models of reef degradation, since both bottom-up and top-down perspectives assume that increased algal abundance will lead to decreased coral abundance, by altering the competitive balance between corals and algae. However, there is relatively little direct experimental evidence that algae do compete, either directly or indirectly, and little information on the relative roles of direct competition and other interactions. Further, it is often assumed that the competitive interactions between corals and algae are relatively uniform, with algae generally competitively superior (Miller 1998, McCook 1999, McCook et al. 2001). However, the available evidence suggests that different types of algae may have very different effects on corals, and much of this variation may be related to properties of the algae, including physical (e.g. size, structure, growth form), biological (e.g. sexual or vegetative mechanisms) and even chemical (allelopathic or secondary metabolites) characteristics. Many of these properties may be effectively summarised in terms of algal functional groups (Littler 1980, Littler \& Littler 1984, Steneck \& Dethier 1994, discussion in McCook et al. 2001).

This study aimed to broaden the range of documented coral-algal interactions, by comparing the effects on corals of 3 different types of macroalgae chosen to represent a range of effects and processes, and of taxonomies. The algae examined include a small, turfing, filamentous red alga Corallophila huysmansii (Ceramiaceae, Ceramiales, Rhodophyta), the larger, filamentous but non-turfing green algae Chlorodesmis spp. (Udoteaceae, Bryopsidales, Chlorophyta), and a corticated red alga Hypnea pannosa (Hypneaceae, Gigartinales, Rhodophyta). Each of these algae were commonly observed living on or in direct contact with live corals and therefore might have negative impacts on the coral tissue. Although work elsewhere has shown filamentous algae to contribute to the death of coral recruits (Birkeland 1977), previous work on our study reefs has suggested that most filamentous, turfing algal species are unable to overgrow live coral tissue (McCook 2001). In contrast, C. huysmansii was observed apparently overgrowing live tissue of the branching coral Porites cylindrica (Fig. 1), with considerable associated damage to the coral tissue. We com-

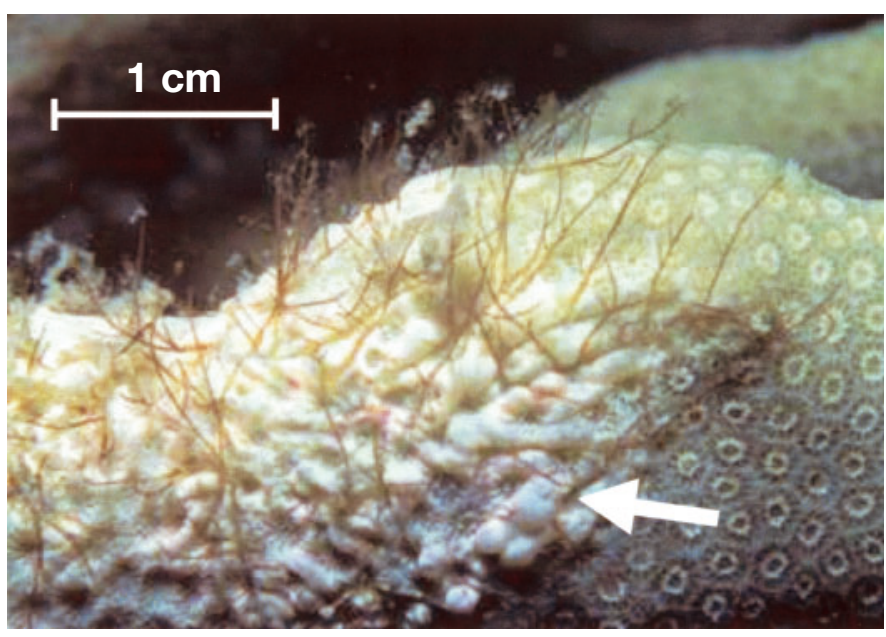

Fig. 1. Corallophila huysmansii. Tissue death of coral Porites cylindrica following overgrowth by filaments of red alga C. huysmansii. Arrow shows swollen coral tissue around algal filaments. Severity of tissue response to such sparse and fine filaments suggests that responsible mechanism may involve allelochemical effects, as the symptoms do not appear consistent with any of the other mechanisms by which algae may affect corals (McCook et al. 2001)

pared the extent to which $C$. huysmansii and general turf algae were able to invade live coral and damage the coral tissue.

Chlorodesmis spp., commonly known as turtle-weed, are bright green, upright (i.e non-turfing), filamentous algae which are widespread and conspicuous on IndoPacific reefs, growing as thick tufts or patches, often surrounded by live coral tissue (Fig. 2), commonly of massive Porites spp. Although common, the algae are rarely if ever abundant or extensive, with patches rarely growing larger than 20 to $30 \mathrm{~cm}$ in diameter. Despite being highly conspicuous, Chlorodesmis spp. patches appear able to persist even in areas with relatively high levels of herbivory, apparently because the filaments contain high levels of a secondary metabolite with herbivore-deterrent properties (Ducker 1976, Paul et al. 1990, Craig et al. 1997). Given this herbivore resistance, it was of interest to explore why the algae do not overgrow larger areas of coral and achieve more extensive patches.

Hypnea pannosa is one of a number of fleshy algae commonly observed growing as mats within the branches of Porites cylindrica colonies (Fig. 3), but with distinctly different structure and growth form than Corallophila huysmansii and Lobophora variegata (Jompa \& McCook 2002a,b), both of which grow on the same coral species. Although technically a corticated alga (i.e. with a differentiated external cell layer, generally resulting in a more robust thallus), $H$. pannosa grows as a reticulate mass, and is relatively brittle, 

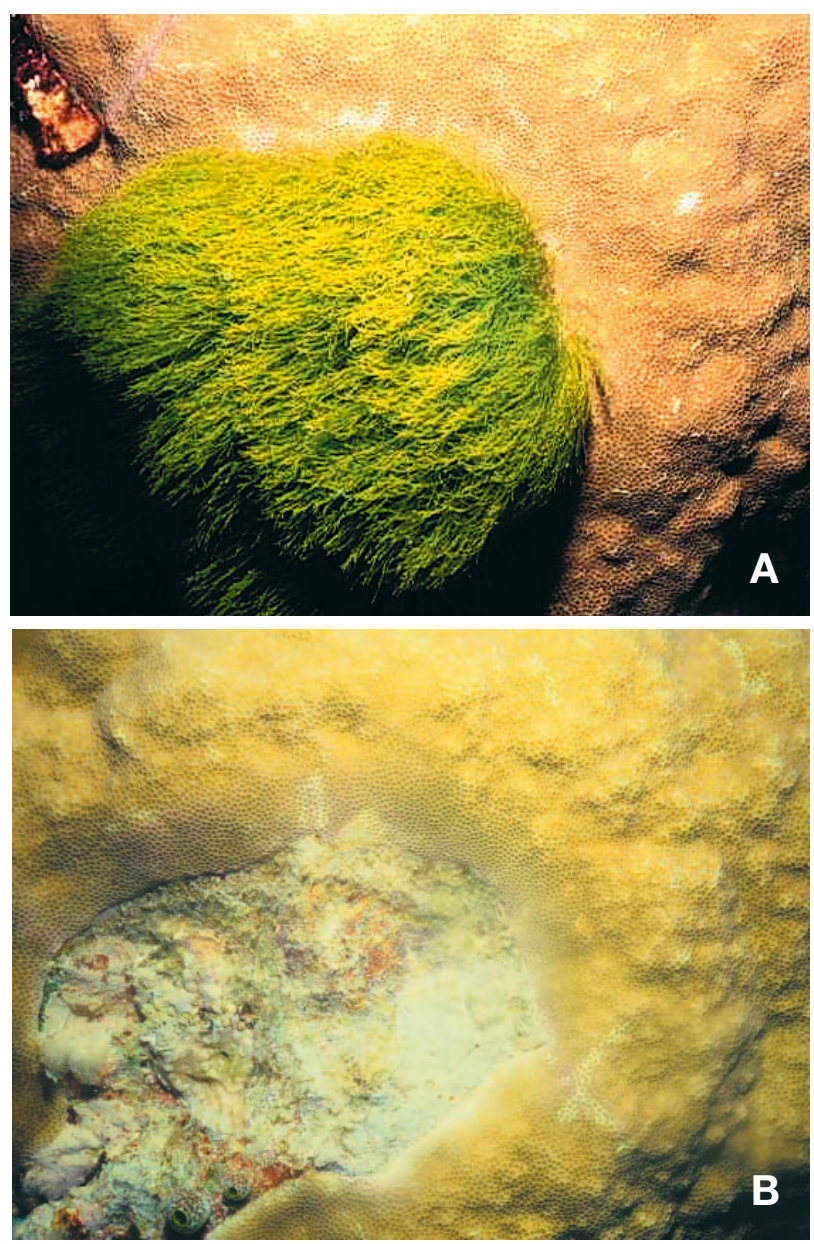

Fig. 2. Chlorodesmis fastigiata ('Turtle Weed') growing amidst live coral on Rib Reef, mid-shelf central GBR. Highly conspicuous tufts apparently deter herbivores by means of secondary metabolites, but nonetheless remain as small patches and do not grow into extensive beds. (A) C. fastigiata plot (February 1999, patch is approximately $10 \mathrm{~cm}$ in diameter); (B) same plot 2 mo later (April 1999) showing seasonal dieback of alga, which died-back and reappeared repeatedly in same plots (see 'Results')

porous and translucent, in contrast to the delicate turfing habit of the filamentous C. huysmansii and the robust, creeping and adherent foliose morphology of the brown foliose alga L. variegata. H. pannosa has been observed in this growth habit on branching corals over wide latitudinal and cross-shelf ranges on the Great Barrier Reef (GBR), and on SE Asian reefs (L. J. McCook unpubl. data). This growth habit, of clumps or mats within branching coral colonies, is relatively common for a range of coral reef algae, including $H$. pannosa, L. variegata, Amansia rhodantha (Ceramiales, Rhodophyta) and various species of Laurencia (Ceramiales, Rhodophyta; L. J. McCook pers. obs.). The $H$. pannosa-P. cylindrica interaction there- fore provides both useful contrasts to other documented interactions and an example of a coral-algal interaction with wide geographic relevance.

\section{MATERIALS AND METHODS}

Study species and sites. The first study, on the interaction between Corallophila huysmansii and Porites cylindrica, was conducted on the reef slope $(7$ to $8 \mathrm{~m}$

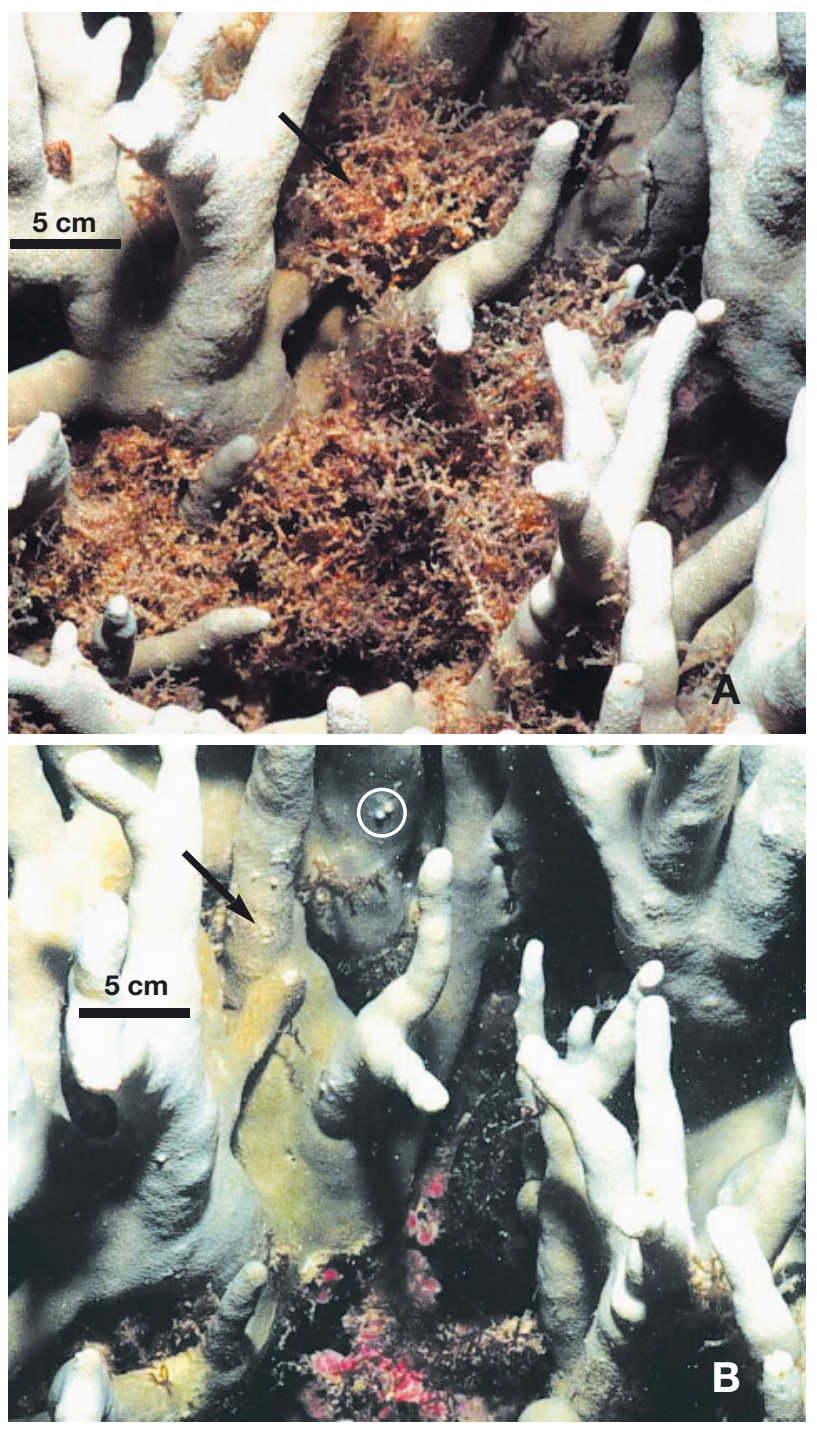

Fig. 3. Hypnea pannosa, a corticated red alga commonly observed growing within branches of Porites cylindrica. Structure of coral branches probably provides refuge for this alga from herbivory (Jompa \& McCook 2003). Coral tissue seemed relatively unaffected by presence of this alga. (A) $H$. pannosa growing within coral branches. (B) Same branches as in (A) a few months later, after manually removing the alga. Arrows indicate coral tissue previously covered by the alga in relatively healthy condition, although darker in colour; minor tissue lesions (e.g. circled in B) were sometimes observed 
depth) at Cannon Bay $\left(18^{\circ} 41.0^{\prime} \mathrm{S}, 146^{\circ} 35.2^{\prime} \mathrm{E}\right)$, Great Palm Island, inshore GBR, Australia, close to the site used by McCook (2001). The site was dominated by large colonies of P. cylindrica ( 65\% cover, based on four $20 \mathrm{~m}$ line-intercept transects), of which many had fleshy macroalgae, especially Lobophora variegata, growing as mats around the bases of branches. During a survey of the site, a number of colonies were found to have the filamentous turfing species $C$. huysmansii growing on live tissue of $P$. cylindrica, usually as relatively small patches $\left(\sim 20 \mathrm{~cm}^{2}\right)$, but occasionally completely overwhelming and killing patches of P. cylindrica up to $1 \mathrm{~m}$ in diameter. Nonetheless, $C$. huysmansii was not abundant, with estimated overall cover at this site less than $2 \%$, and few observations at other sites.

The effect of Hypnea pannosa on Porites cylindrica was investigated on the reef crest ( 3 to $5 \mathrm{~m}$ ) at Little Pioneer Bay ( $\left.18^{\circ} 36.0^{\prime} \mathrm{S}, 146^{\circ} 29.3^{\prime} \mathrm{E}\right)$, Orpheus Island, inshore GBR. P. cylindrica was also abundant at this site, but, in contrast to Cannon Bay, the dominant macroalga growing within the coral branches at this site was $H$. pannosa. Patches of the alga varied in size, from about $20 \mathrm{~cm}^{2}$ to $2 \mathrm{~m}^{2}$, with mats generally between 5 to $10 \mathrm{~cm}$ thick, and in much greater abundance than Corallophila huysmansii.

The interaction between Chlorodesmis spp. and corals was monitored at a reef-flat site (1 to $2 \mathrm{~m}_{\text {; }}$ $\left.18^{\circ} 28.5^{\prime} \mathrm{S}, 146^{\circ} 52.7^{\prime} \mathrm{E}\right)$ and a reef slope site ( 8 to $10 \mathrm{~m}$; $\left.18^{\circ} 28.4^{\prime} \mathrm{S}, 146^{\circ} 52.8^{\prime} \mathrm{E}\right)$ on Rib Reef, a mid-shelf reef on the central GBR. The algae occupied small patches amidst live tissue of massive Porites spp. (predominantly P. lobata) and Favites spp., and encrusting Montipora spp. Chlorodesmis spp. filaments were in direct contact with surrounding coral tissue. Although most of the Chlorodesmis patches studied were C. fastigiata, several of the reef slope patches were comprised of $C$. major. However, as their effects on corals were indistinguishable, both species are treated together as Chlorodesmis spp. Chlorodesmis spp. do have basal rhizomes, but these do not form the extensive horizontal filaments seen in typical turfing morphologies (e.g. C. huysmansii, see Price \& Scott 1992 for details). The Chlorodesmis spp. patches were very common (and easily noticed), but relatively small, so that overall abundance was low.

Expt 1: Corallophila huysmansii. To examine the ability of $C$. huysmansii to colonise and kill live coral tissue, we compared the effects of this alga on mortality of coral tissue with the effect of other mixed turfing and crustose coralline algae. We did this by attempting to 'infect' or induce colonisation of healthy Porites cylindrica branches with either $C$. huysmansii or with general mixed algal turfs. Using a small hand-saw, we carefully removed 9 live branches of $P$. cylindrica (approx. $2 \mathrm{~cm}$ thick and $6 \mathrm{~cm}$ long) with $C$. huysmansii present and attached them to 9 randomly selected healthy coral branches using cable ties ( $C$. huysmansii infection treatment). Similarly, 9 other dead coral branches, overgrown by general mixed algal turfs and coralline algae, were attached to healthy coral branches ('mixed algal infection'), adjacent to $(\sim 30 \mathrm{~cm}$ apart) 1 of the branches infected by C. huysmansii (mixed turfs did not occur on live coral tissue). Experimental branches were approximately $2 \mathrm{~m}$ apart. The effect of the algae on the coral was estimated as the area $\left(\mathrm{mm}^{2}\right)$ of coral tissue mortality associated with the algal infection, measured with vernier callipers every 5 to $8 \mathrm{wk}$ for 6 to $7 \mathrm{mo}$. The experiment was run at 2 different times of the year to assess temporal or seasonal variability in the interaction. The first period was from August 1998 to March 1999, the second from May to November 1999.

Algal overgrowth in these experiments was generally relatively short-lived ( 3 to $4 \mathrm{mo}$ ). To investigate whether this reflected intrinsic seasonality or senescence of the alga, a number of Corallophila huysmansiiovergrown branches were collected to determine their longevity in aquaria. Branches were anchored by glueing to clay tiles, transplanted, and maintained under running seawater at the James Cook University aquarium. Algal condition was regularly observed for 6 mo (concurrently with the second experimental period in May to November 1999).

Expt 2: Hypnea pannosa. The effects of $H$. pannosa on Porites cylindrica were assessed by comparing coral growth and mortality in quadrats in which the alga was naturally present or experimentally removed. We marked 16 plots $(50 \times 50 \mathrm{~cm})$ within P. cylindrica colonies that had extensive mats of $H$. pannosa alga growing within the coral branches. The alga was removed from 8 randomly selected plots $(H$. pannosa removal treatment) and was left intact on the other 8 plots as controls (H. pannosa present).

To compare coral growth and tissue mortality between treatments, 4 individual branches were randomly chosen within each plot and marked with plastic labels attached by cable ties onto the basal part of the branch. Coral tissue mortality was estimated for the tagged coral branches as the change in area $\left(\mathrm{mm}^{2}\right)$ of dead coral tissue, using callipers (as for Expt 1). Coral growth was estimated as linear skeletal extension measured from the marker (cable tie) to the tip of each coral branch. This experiment ran for $1.5 \mathrm{yr}$ from April 1998 to October 1999.

Expt 3: Chlorodesmis spp. The potential effects of the filamentous green algae Chlorodesmis spp. on surrounding corals were investigated by monitoring Chlorodesmis spp. patches, to identify any apparent stresses or impacts. On both the reef flat and reef slope at Rib Reef, we marked 15 small permanent quadrats 
$(14.5 \times 21.5 \mathrm{~cm})$ containing patches of Chlorodesmis spp. completely surrounded by live coral tissue, and monitored them photographically. Quadrats were photographed using a Nikonos V camera with $28 \mathrm{~mm}$ lens and close-up kit; algal filament heights were measured manually, and qualitative observations of coral condition were noted every 2 to $3 \mathrm{mo}$ for $18 \mathrm{mo}$, from September 1998 to March 2000.

Data analyses. Data analyses for Expts 1 and 2 involved a simple 1-way ANOVA (using data from end of each experiment) and a nested ANOVA with plots nested within treatments, respectively. All data were tested for homogeneity of variance (Cochran's test), outliers, and independence and normality of residuals. Based on these tests, data transformation was unnecessary for Expt 2. Data for Expt 1 were log-transformed because temporal changes differed by orders of magnitude between treatments, resulting in heteroscedasticity in the untransformed data. Qualitative observations of Chlorodesmis spp. effects only are presented, since no significant coral tissue mortality was recorded for these algae.

\section{RESULTS}

\section{Expt 1: Corallophila huysmansii}

Corallophila huysmansii was able to colonise and overgrow live Porites cylindrica tissue, and overgrowth by even relatively sparse filaments of $C$. huysmansii appeared to cause considerable damage to underlying and adjacent coral tissue (e.g. Fig. 1). Coral tissue became bleached and swollen even up to several millimetres away from algal filaments, and subsequently died; this only occurred adjacent to algal filaments, and was not observed in coral tissue adjacent to areas of live $P$. cylindrica branches without the alga present. The results provide strong evidence that overgrowth by $C$. huysmansii was the direct cause of coral tissue death. Coral tissue mortality was significantly higher in the C. huysmansii infection treatment than on corals infected by mixed algal turfs, during both periods (Fig. 4, Table 1). About $1 \mathrm{mo}$ after C. huysmansii branches had been placed in contact with healthy coral branches, the alga had colonised and overgrown the healthy coral tissue. Although only a little coral tissue actually died within that time, the rest of the overgrown tissues were clearly severely stressed (Fig. 1). Coral tissue mortality appeared to generally follow overgrowth, but with a delay of up to several months; dead coral tissue was subsequently occupied by mixed-species, filamentous algal turfs. Thus, although Fig. 4 shows an increase in coral mortality toward the end of both experimental periods, algal colonisation
Table 1. Corallophila huysmansii. ANOVAs of effects of 'infection' by either $C$. huysmansii or mixed filamentous turfs on coral tissue mortality. Data are transformed to $\log _{10}(x+1)$, and analyzed independently for the first and second periods using data from final measurements for each period

\begin{tabular}{|lrrrr|}
\hline Source & df & MS & $F$ & $p$ \\
\hline First period (Aug 98 to Mar 99) & & & & \\
$\quad$ Treatment & 1 & 38.0 & 46.2 & $<0.001$ \\
$\quad$ Residual & 16 & 0.8 & & \\
Second period (May to Nov 99) & & & & \\
$\quad$ Treatment & 1 & 24.7 & 22.7 & $<0.001$ \\
$\quad$ Residual & 16 & 1.1 & & \\
\hline
\end{tabular}

had generally ceased by that time, and only very few coral branches still had small amounts of $C$. huysmansii filaments growing on live coral tissue. Algal overgrowth of new live coral tissue generally ceased within 2 to 6 mo. Comparison of the 2 experimental periods suggests that the time course of colonisation

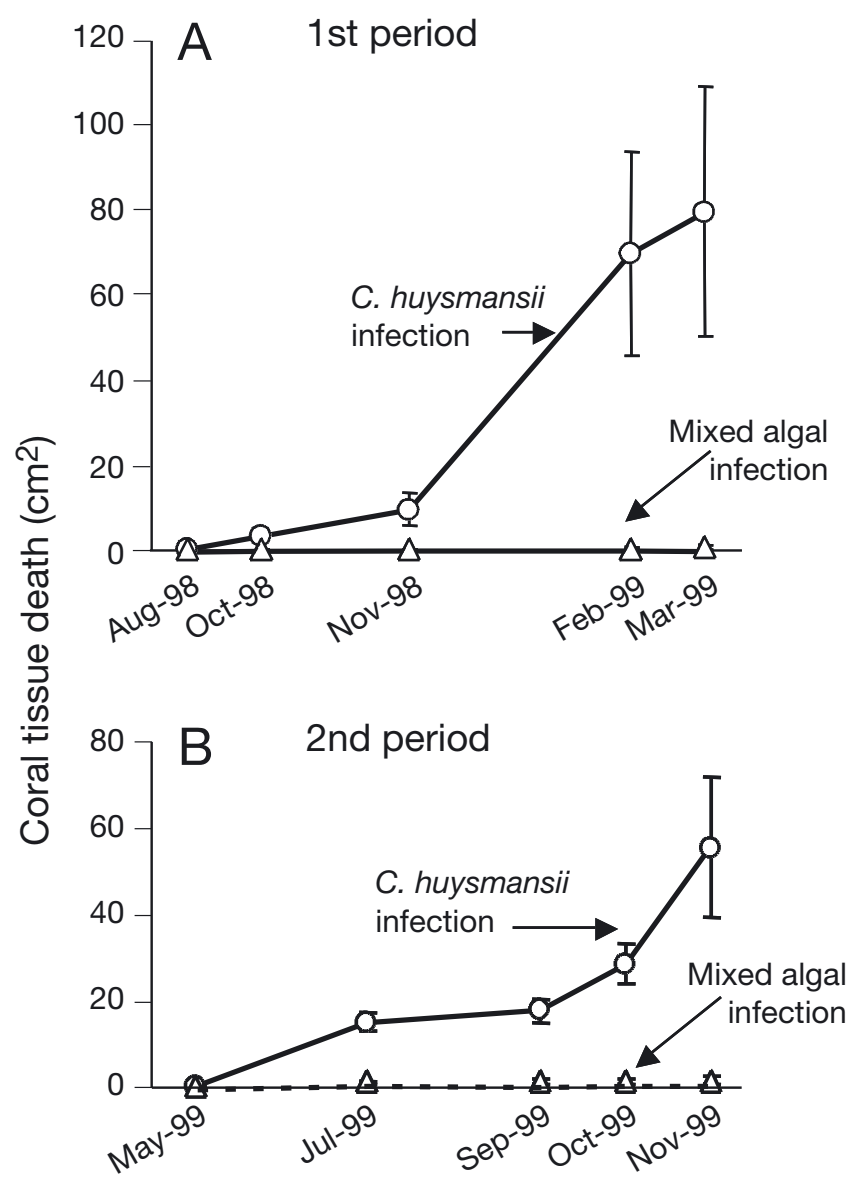

Fig. 4. Corallophila huysmansii. Coral tissue mortality of branches 'infected' by C. huysmansii and mixed algal turfs. Data are means $( \pm \mathrm{SE})$ of total coral-tissue death $\left(\mathrm{cm}^{2}\right)$ for 9 replicates 
was similar at both times of year, with little seasonal difference (Fig. 4). Interestingly, in contrast to the field experiments, C. huysmansii transplanted to aquaria continued to grow well over new coral substrate for up to $6 \mathrm{mo}$, and attained upright filament heights longer than those in the field.

In contrast to the Corallophila huysmansii treatment, the mixed algal turfs and crustose corallines were relatively poor competitors with healthy Porites cylindrica. Coral branches in the mixed algal treatment showed only minor tissue mortality during the first month, and otherwise generally remained healthy throughout the study periods. In a few cases, coral tissue even grew from the healthy coral branch over the mixed algal communities on the experimentally attached, dead coral branches.

\section{Expt 2: Hypnea pannosa}

The presence of Hypnea pannosa had minimal effects on both coral tissue mortality and growth during this experiment. Coral tissue mortality in both treatments was minimal, indicating that $H$. pannosa had not caused significant damage to underlying coral tissue. Coral tissue underneath the algal mat was generally healthy, although a little darker in colour, with only a few minor tissue-lesions (Fig. 3). Quantitative results are not given because tissue mortality was insufficient to quantify. Although growth (or linear skeletal extension) of Porites cylindrica branches was very slightly higher in the absence of $H$. pannosa than in plots with the alga present, this difference was very small and not significant (Fig. 5, Table 2).

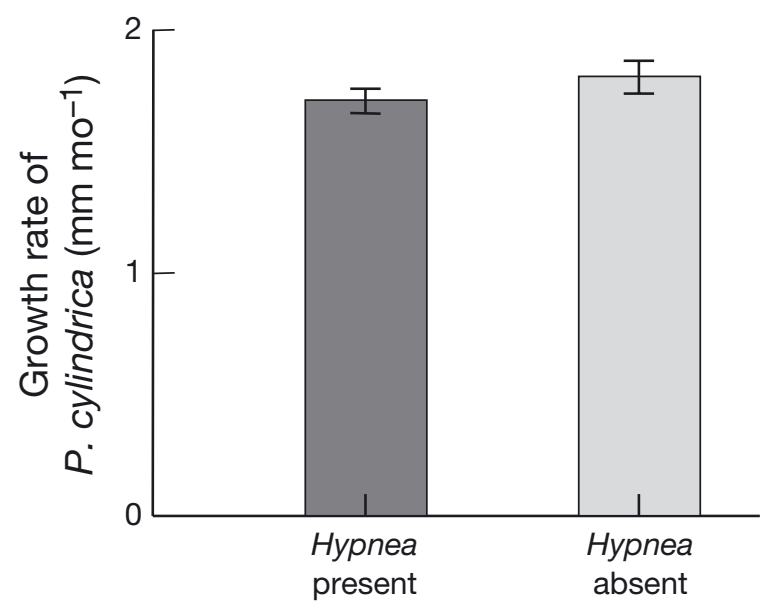

Fig. 5. Hypnea pannosa. Growth rate of Porites cylindrica in plots with $H$. pannosa present or experimentally removed. Data are means $( \pm \mathrm{SE})$ of coral growth rate of 32 replicates averaged over 4 plots
Table 2. Hypnea pannosa. ANOVA of effect on growth rate of Porites cylindrica. Homogeneity of variance test shown as Cochran's $C$, critical value of $C$ here is 0.26 ; data are untransformed

\begin{tabular}{|lrccc|}
\hline Source & df & MS & $F$ & $\mathrm{p}$ \\
\hline Treatment & 1 & 0.15 & 1.37 & 0.261 \\
Plot (treatment) & 14 & 0.11 & 0.97 & 0.492 \\
Residual (n=4) & 48 & 0.11 & & \\
Cochran's $C=0.24$ & & & & \\
\hline
\end{tabular}

\section{Expt 3: Chlorodesmis spp.}

Coral tissue in direct contact with Chlorodesmis spp. filaments showed minimal tissue damage even after 18 mo of monitoring. Direct observations showed that longer algal filaments (5 to $10 \mathrm{~cm}$ in length), although very soft, would constantly brush adjacent coral tissue as the filaments moved with water motion, with the frequent consequence that coral polyps in the vicinity of the filaments were retracted, and the tissue showed minor stress symptoms such as pale colouration or a pink speckled appearance.

Both photographic monitoring and filament height measurements showed that Chlorodesmis spp. patches undergo a dramatic cycle in standing crop, with a periodic loss and reappearance or regrowth of most macroscopic filaments. Although the periodicity of this cycle is difficult to determine from intermittent photographs/ visits, and appeared to vary between patches, it appears that individual patches can undergo at least 1 complete cycle within 4 to 6 mo (e.g. Fig. 2). Of the 15 Chlorodesmis spp. patches initially marked in each zone, after $18 \mathrm{mo}, 12$ were still present on the reef flat and 6 on the reef slope.

\section{DISCUSSION}

The results in this paper, taken together with those of several other recent studies (Table 3), considerably extend the range of taxa, algal and coral types, and outcomes of documented coral-algal interactions. They also further illustrate the considerable variation possible in both processes and outcomes of these interactions (Miller 1998), and provide an opportunity to review the ideas about variability in mechanisms and outcomes proposed by McCook et al. (2001). This 'mechanisms approach' argues that there are a limited number of mechanisms by which corals can affect algae, and vice versa, and that consideration of the properties of the algae provides useful clues as to which of those mechanisms may be relevant (e.g. sparse filamentous algae are unlikely to have strong 
Table 3. Comparison of recent studies demonstrating range of competitive effects of algae on corals and potential mechanisms and apparent effects of different types of algae on corals. Algal properties clearly provide valuable indications of potential competitive mechanisms and consequent effects. Many of those properties are effectively summarized by the functional groups, with the clear exception of allelochemical properties. (This table provides an update to Tables 1 to 4 in McCook et al. 2001)

\begin{tabular}{|c|c|c|c|c|}
\hline Algae & Functional group & Potential mechanism & Effect on corals & Source \\
\hline Mixed algal turfs & Filamentous (turf) & Vary & No major effect & $\begin{array}{l}\text { McCook (2001), } \\
\text { Jompa \& McCook } \\
\text { (2003, this volume), } \\
\text { present study }\end{array}$ \\
\hline Corallophila huysmansii & Filamentous (turf) & Allelochemical? & Coral tissue mortality & Present study \\
\hline Anotrichium tenue & Filamentous (turf) & $\begin{array}{l}\text { Allelochemical? } \\
\text { (+ sediment trapping) }\end{array}$ & $\begin{array}{l}\text { Coral tissue } \\
\text { mortality }\end{array}$ & $\begin{array}{l}\text { Jompa \& McCook } \\
(2003, \text { this volume })\end{array}$ \\
\hline Chlorodesmis spp. & Filamentous (non-turf) & Abrasion & No major effect & Present study \\
\hline Lobophora variegata & Creeping corticate foliose & Overgrowth & $\begin{array}{l}\text { Coral tissue } \\
\text { mortality }\end{array}$ & $\begin{array}{l}\text { Jompa \& McCook } \\
(2002 a, b)\end{array}$ \\
\hline Hypnea pannosa & Corticated macrophyte & $\begin{array}{l}\text { Shading and/or } \\
\text { overgrowth }\end{array}$ & $\begin{array}{l}\text { No major effect/ } \\
\text { minor tissue damage }\end{array}$ & Present study \\
\hline $\begin{array}{l}\text { Sargassum spp. } \\
\text { Cystoseira spp. + } \\
\text { Turbinaria spp. }\end{array}$ & $\begin{array}{l}\text { (Canopy-forming) } \\
\text { Leathery macrophytes }\end{array}$ & $\begin{array}{l}\text { Shading and/or abrasion } \\
\text { and/or physical barrier }\end{array}$ & $\begin{array}{l}\text { Reduced coral } \\
\text { bleaching }\end{array}$ & $\begin{array}{l}\text { Jompa \& McCook } \\
\text { (1998, unpubl. data) }\end{array}$ \\
\hline
\end{tabular}

shading effects; see also Fig. 1 of present paper). The different algal taxa examined in this study demonstrate strongly contrasting effects on corals, with 1 filamentous taxon (Corallophila huysmansii) causing severe coral tissue damage even at some distance from the filaments, and others (general mixed algal turfs, Hypnea pannosa and Chlorodesmis spp.) causing negligible damage.

It appears that much of this variation can be interpreted in terms of the properties of the algae, and the consequent mechanisms by which they affect the adjacent coral tissue by direct overgrowth, shading, abrasion or chemical effects (or by pre-emption of space and recruitment inhibition: McCook et al. 2001). Thus, although corticated algae are generally more robust than filamentous taxa, Hypnea pannosa is a relatively fragile example of the corticated functional group (Littler 1980, Steneck \& Dethier 1994), and its relatively porous, reticulate structure and translucent thallus apparently do not limit water flow (with associated gas and nutrient exchange) or light availability sufficiently to seriously inhibit coral growth or survival. Chlorodesmis spp., although generally longer and more robust than Corallophila huysmansii, do not have a turfing growth habit, and have limited ability to vegetatively overgrow and colonise new substrate. Although they appear to cause polyp retraction, the effect is minor, perhaps because their filaments are relatively soft, or because the seasonal dieback provides adjacent coral with an opportunity to recover, or because the coral colony is able to subsidise the areas with retracted polyps by translocation of metabolites.
In contrast, the relatively delicate filaments of Corallophila huysmansii can very effectively colonise and kill healthy coral tissue. The turfing growth habit of $C$. huysmansii allows it to rapidly invade new substrate, but this alone cannot explain its ability to colonise live coral tissue, as many of the taxa present in the (relatively harmless) mixed filamentous turfs have similar growth habits. Thus, whatever factor provides C. huysmansii with the ability to colonise live coral tissue is critical to the competitive effectiveness of this taxon.

The relatively short life-span of Corallophila huysmansii in the field experiments is intriguing. Its greater longevity in aquaria, along with the occasional occurrence of large patches of Porites cylindrica overgrown by $C$. huysmansii, suggests that its dieback in the field is not due to intrinsic seasonality or senescence, but to other factors. Although the longevity of C. huysmansii in aquaria may reflect competitive advantages conferred by the lack of herbivores or elevated nutrient conditions, this remains strictly speculative without further evidence.

The apparent ability of Corallophila huysmansii to kill coral tissue relatively distant from its fine filaments (Fig. 1) raises the possibility of allelochemical effects (see e.g. de Nys et al. 1991 for details of algal effects on soft coral). Although we do not have direct chemical evidence, it is difficult to explain the nature of the effect by any of the other mechanisms by which algae are known to inhibit corals (McCook et al. 2001): the pattern of tissue death apparent in Fig. 1 is hard to reconcile with overgrowth (smothering), shading, or abrasion (pre-emption and epithelial sloughing are not relevant here). Thus the mechanisms approach 
(McCook et al. 2001) is able to suggest an explanation for the strength of effects of C. huysmansii on Porites cylindrica interaction without direct evidence.

This approach is also effective for results from other studies. Like Hypnea pannosa, the foliose brown alga Lobophora variegata also grows amidst the basal branches of Porites cylindrica colonies, but in contrast to $H$. pannosa, $L$. variegata occurs in an adherent, creeping form and has a relatively robust and opaque foliose thallus which effectively blocks light and water flow. The apparent consequence is that, again in contrast to $H$. pannosa, $L$. variegata can overgrow and kill P. cylindrica (Jompa \& McCook 2002a,b). Large, canopy-forming leathery macrophytes had relatively minor effects on understory corals, even apparently protecting them from bleaching damage by shading (Jompa \& McCook 1998). Such algal canopies are unlikely to smother corals, as their small holdfasts occupy relatively little primary substrate; however, their extensive canopies can shade or abrade corals. Further illustrations of this approach for other published studies (e.g. Fishelson 1973, Potts 1977, Hughes 1994, Tanner 1995, Miller \& Hay 1996) are reviewed by McCook et al. (2001).

Interestingly, of the interactions documented in Table 3 and McCook et al. (2001), smothering and the putative chemical effects appear relatively lethal to corals, whereas shading and abrasion effects appear less severe. Note also that chemically mediated interactions constitute a limitation to the functional group approach suggested for coral-algal competition by McCook et al. (2001): although much of the variability in coral-algal interactions can be explained by algal properties that are effectively summarised by accepted functional groups (Littler 1980, Steneck \& Dethier 1994), allelochemical effects are not predicted by these groups.

In summary, the present results expand the range of documented coral-algal interactions, and emphasise the potential variability in both processes and outcomes of those interactions. Importantly, that variability can be effectively interpreted in terms of the properties of the algae, and the potential mechanisms by which they can affect the corals. Better interpretation and understanding of the variability in coral-algal interactions could enable more effective prediction of the outcomes and consequences of coral-algal dynamics under varying circumstances, with significant consequences in the context of reef degradation.

Acknowledgements. We wish to thank T. Done, M. and D. Littler, J. Tanner, T. Hughes, M. Miller and R. Steneck for discussion, J. Skeat for comments on the manuscript, and numerous field assistants. We acknowledge the support of the Australian Institute of Marine Science and the CRC: Reef Research Centre.

\section{LITERATURE CITED}

Aronson RB, Precht WF (2000) Herbivory and algal dynamics on the coral reef at Discovery Bay, Jamaica. Limnol Oceanogr 45:251-255

Bell PRF (1992) Eutrophication and coral reefs - some examples in the Great Barrier Reef lagoon. Water Res 26: 553-568

Birkeland C (1977) The importance of rate of biomass accumulation in early successional stages of benthic communities to the survival of coral recruits. Proc 3rd Int Coral Reef Symp 1:15-21

Craig PC, Choat JH, Axe LM, Saucerman S (1997) Population biology and harvest of the coral reef surgeonfish Acanthurus lineatus in American Samoa. Fish Bull US Fish Wildl Serv 95:680-693

de Nys R, Coll JC, Price IR (1991) Chemically mediated interactions between the red alga Plocamium hamatum (Rhodophyta) and the octocoral Sinularia cruciata (Alcyonacea). Mar Biol 108:315-320

Done TJ (1992) Phase shifts in coral reef communities and their ecological significance. Hydrobiologia 247:121-132

Ducker SC (1976) The genus Chlorodesmis (Chlorophyta) in the Indo-Pacific region. Nova Hedwigia 13:145-182, pls 25-43

Fishelson L (1973) Ecological and biological phenomena influencing coral-species composition on the reef tables at Eilat (Gulf of Aqaba, Red Sea). Mar Biol 19:183-196

Hanisak MD (1979) Nitrogen limitation of Codium fragile ssp. tomentosoides as determined by tissue analysis. Mar Biol 50:333-337

Hay ME (1981) Herbivory, algal distribution, and the maintenance of between-habitat diversity on a tropical fringing reef. Am Nat 118:520-540

Hay ME (1984) Predictable spatial escapes from herbivory: how do these affect the evolution of herbivore resistance in tropical marine communities? Oecologia 64:396-407

Hughes TP (1994) Catastrophes, phase shifts, and large-scale degradation of a Caribbean coral reef. Science 265: $1547-1551$

Hughes TP, Szmant AM, Steneck R, Carpenter R, Miller S (1999) Algal blooms on coral reefs: what are the causes? Limnol Oceanogr 44:1583-1586

Jompa J, McCook LJ (1998) Seaweeds save the reefs?!: Sargassum canopy decreases coral bleaching on inshore reefs. Reef Res 8:5

Jompa J, McCook LJ (2002a) Effects of herbivory and competition on interactions between a hard coral and a brown alga. J Exp Mar Biol Ecol 271:25-39

Jompa J, McCook LJ (2002b) The effect of nutrients and herbivory on competition between a hard coral (Porites cylindrica) and a brown alga (Lobophora variegata). Limnol Oceanogr 47:527-534

Jompa J, McCook LJ (2003) Contrasting effects of turf algae on corals: massive Porites spp. are unaffected by mixedspecies turfs, but killed by the red alga Anotrichium tenue. Mar Ecol Prog Ser 258:79-86

Karlson RH (1999) Dynamics of coral communities. Kluwer Academic Publishers, Dordrecht

Lang JC, Chornesky EA (1990) Competition between scleractinian reef corals - a review of mechanisms and effects. Dubinsky Z (ed) Ecosystems of the world: coral reefs. Elsevier Press, Amsterdam, p 209-252

Lapointe BE (1997) Nutrient thresholds for bottom-up control of macroalgal blooms on coral reefs in Jamaica and southeast Florida. Limnol Oceanogr 42:1119-1131

Lapointe BE (1999) Simultaneous top-down and bottom-up 
forces control macroalgal blooms on coral reefs (reply to the comment by Hughes et al.). Limnol Oceanogr 44: $1586-1592$

Lewis SM (1985) Herbivory on coral reefs: algal susceptibility to herbivorous fishes. Oecologia 65:370-375

Lewis SM (1986) The role of herbivorous fishes in the organization of a Caribbean reef community. Ecol Monogr 56: $183-200$

Littler MM (1980) Morphological form and photosynthesis performances of marine macroalgae: tests of a functionalform hypothesis. Bot Mar 22:161-165

Littler MM, Littler DS (1984) Models of tropical reef biogenesis: the contribution of algae. Prog Phycol Res 3:323-363

McCook LJ (1996) Effects of herbivores and water quality on the distribution of Sargassum on the central Great Barrier Reef: cross-shelf transplants. Mar Ecol Prog Ser 139:179-192

McCook LJ (1997) Effects of herbivory on zonation of Sargassum spp. within fringing reefs of the central Great Barrier Reef. Mar Biol 129:713-722

McCook LJ (1999) Macroalgae, nutrients and phase shifts on coral reefs: scientific issues and management consequences for the Great Barrier Reef. Coral Reefs 18:357-367

McCook LJ (2001) Competition between coral and algal turfs along a gradient of terrestrial influence in the nearshore central Great Barrier Reef. Coral Reefs 19:419-425

McCook LJ, Jompa J, Diaz-Pulido G (2001) Competition between corals and algae on coral reefs: a review of available evidence and mechanisms. Coral Reefs 19:400-417

Miller MW (1998) Coral/seaweed competition and the control of reef community structure within and between latitudes. Oceanogr Mar Biol Annu Rev 36:65-96

Miller MW, Hay ME (1996) Coral-seaweed-grazer-nutrient interactions on temperate reefs. Ecol Monogr 66:323-344

Naim O (1993) Seasonal responses of a fringing reef com-

Editorial responsibility: Charles Birkeland (Contributing Editor), Honolulu, Hawaii, USA munity to eutrophication (Reunion Island, Western Indian Ocean). Mar Ecol Prog Ser 99:137-151

Pastorok RA, Bilyard GR (1985) Effects of sewage pollution on coral-reef communities. Mar Ecol Prog Ser 21:175-189

Paul VJ, Nelson SG, Sanger HR (1990) Feeding preferences of adult and juvenile rabbitfish Siganus argenteus in relation to chemical defenses of tropical seaweeds. Mar Ecol Prog Ser 60:23-34

Potts DC (1977) Suppression of coral population by filamentous algae within damselfish territories. J Exp Mar Biol Ecol 28:207-216

Price IR, Scott FJ (1992) The turf algal flora of the Great Barrier Reef. Part I. Rhodophyta. James Cook University of North Queensland, Townsville

Russ GR, McCook LJ (1999) Potential effects of a cyclone on benthic algal production and yield to grazers on coral reefs across the central Great Barrier Reef. J Exp Mar Biol Ecol 235:237-254

Schaffelke B (1999) Short-term nutrient pulses as tools to assess responses of coral reef macroalgae to enhanced nutrient availability. Mar Ecol Prog Ser 182:305-310

Schaffelke B, Klumpp DW (1998) Nutrient-limited growth of the coral reef macroalga Sargassum baccularia and experimental growth enhancement by nutrient addition in continuous flow culture. Mar Ecol Prog Ser 164:199-211

Smith SV, Kimmerer WJ, Laws EA, Brock RE, Walsh TW (1981) Kaneohe Bay sewage diversion experiment: perspectives on ecosystem responses to nutritional perturbation. Pac Sci 35:279-385

Steneck RS, Dethier MN (1994) A functional group approach to the structure of algal-dominated communities. Oikos 69:476-498

Tanner JE (1995) Competition between scleractinian corals and macroalgae: an experimental investigation of coral growth, survival and reproduction. J Exp Mar Biol Ecol 190:151-168

Submitted: December 12, 2001; Accepted: February 17, 2003 Proofs received from author(s): August 4, 2003 